\title{
Estimation of the Proportion of Feed Protein Digested in the Small Intestine of Cattle Consuming Wet Corn Gluten Feed ${ }^{1}$
}

\author{
P. J. Kononoff, ${ }^{2}$ S. K. Ivan, ${ }^{3}$ and T. J. Klopfenstein \\ Department of Animal Science, University of Nebraska-Lincoln, Lincoln, 68583-0908
}

\begin{abstract}
The objectives of this study were to expand the database and determine the intestinal digestibility of rumen undegradable protein (dRUP) of common dairy feeds and to determine the effects of feeding $37.9 \%$ wet corn gluten feed on these estimates. Two ruminally and duodenally fistulated steers were assigned randomly to a crossover design with 4 -wk periods. The mobile bag technique was used to determine rumen undegradable protein (RUP), dRUP, total tract digestible protein, and total tract digestible dry matter of alfalfa hay, brome hay, alfalfa haylage, corn silage, whole cottonseed, soybean meal, soyhulls, ground corn, nonenzymatically browned soybean meal, and dried distillers grains. There was no consistent effect of diet on RUP, dRUP, total tract digestible protein, and total tract digestible dry matter. The RUP (\% of crude protein) ranged from $5.97 \%$ for alfalfa haylage to $75.6 \%$ for nonenzymatically browned soybean meal. The dRUP ranged from $15.3 \%$ for alfalfa haylage to $96.5 \%$ for nonenzymatically browned soybean meal. The dRUP for alfalfa hay $(33.9 \%)$, brome hay $(39.1 \%)$, alfalfa haylage (15.5\%), and corn silage (19.9\%) were lower than National Research Council reported values. The higher dRUP of the nonenzymatically browned soybean meal is reflective of more total protein reaching the small intestine. The large range in dRUP was not reflected in total tract digestible protein (\% of crude protein), with corn silage being the lowest at $85.2 \%$ and nonenzymatically browned soybean meal the highest at $97.9 \%$. In this study, diet had little effect on intestinal digestibility of protein or dry matter.
\end{abstract}

Key words: mobile bag, intestinal digestibility, rumen undegradable protein

\footnotetext{
Received August 23, 2006.

Accepted January 19, 2007.

${ }^{1}$ A contribution of the University of Nebraska Agricultural Research Division, supported in part by funds provided through the Hatch Act.

${ }^{2}$ Corresponding author: pkononoff2@unl.edu

${ }^{3}$ Current address: Department of Animal and Avian Sciences, University of Maryland, College Park, MD 20742.
}

\section{INTRODUCTION}

The current NRC publication, Nutrient Requirements of Dairy Cattle (NRC, 2001), outlines the fate of dietary protein: ruminal fermentation and digestion, intestinal hydrolytic and enzymatic digestion, or passage of indigestible components with the feces. In this system, feed CP is characterized as being either RDP or RUP. Because RUP may be a direct source of AA for the animal, its contribution to the MP pool is, in part, a function of the proportion of protein digested in the small intestine and how much reaches the small intestine. Unfortunately, the data needed to provide estimates on intestinal RUP digestibility (dRUP) are limited (Schwab et al., 2003). This topic is further complicated because the adaptive response of digestive processes in the small intestine from manipulations in the diet is not well understood (Harmon, 1993). As a consequence, more research is needed to provide consistent estimates of dRUP and to further understand the factors affecting it.

Wet corn gluten feed (WCGF), a co-product of the wet milling industry, is largely composed of corn bran and steep liquor but may also contain varying amounts of distillers solubles, germ meal, and kernel screenings (Macken et al., 2004). Although the chemical composition may vary, WCGF contains approximately $24 \% \mathrm{CP}$, $30 \%$ of which is undegradable in the rumen (NRC, 2001). Several recent studies have demonstrated that WCGF may constitute $>35 \%$ of the ration DM (Boddugari et al., 2001; Kononoff et al., 2006). However, addition of WCGF may affect ruminal mat characteristics, which may alter passage of feed from the rumen and digestion rates of feed in the rumen (Allen and Grant, 2000). Because differences in passage and digestion may change the composition and amount of material reaching the small intestine, the impact of WCGF on the digestibility of material in the small intestine should be investigated. The objectives of this study were to 1) expand the database and determine the dRUP of common dairy feeds, and 2) determine the effects of feeding WCGF on intestinal dRUP and total tract CP and DM digestibility. 
Table 1. Ingredient and chemical composition of the total mixed diets (DM basis)

\begin{tabular}{lrr}
\hline & \multicolumn{2}{c}{ Diet $^{1}$} \\
\cline { 2 - 3 } Item & Control & WCGF \\
\hline Diet ingredient & & \\
Alfalfa haylage & 17.8 & 10.4 \\
Alfalfa hay & 12.0 & 8.5 \\
Corn silage & 29.8 & 18.9 \\
Wet corn gluten feed & - & 37.9 \\
Cottonseed & 8.7 & 5.1 \\
Ground corn & 20.3 & 12.5 \\
Nonenzymatically browned soybean meal $^{2}$ & 1.7 & 1.7 \\
Tallow & 0.7 & 1.0 \\
Soybean meal, 48\% & 6.0 & 0.9 \\
Urea & 1.0 & - \\
Bloodmeal & 0.6 & 0.5 \\
Mineral-vitamin premix & \\
Chemical composition & 2.3 & 2.9 \\
DM, \% & & \\
CP, \% of DM & 63.0 & 62.0 \\
NDF, \% of DM & 18.2 & 20.0 \\
Ash, \% of DM & 34.2 & 34.9 \\
\hline
\end{tabular}

${ }^{1}$ Control = ration containing no amount of wet corn gluten feed; $\mathrm{WCGF}=$ ration containing wet corn gluten feed .

${ }^{2}$ LignoTech (Rothschild, WI).

${ }^{3}$ Contained $1.0 \% \mathrm{Ca}, 0.50 \% \mathrm{P}, 0.36 \% \mathrm{Mg}, 1.3 \% \mathrm{~K}, 120,000 \mathrm{IU} / \mathrm{d}$ of vitamin $\mathrm{A}, 24,000 \mathrm{IU} / \mathrm{d}$ of vitamin $\mathrm{D}$, and $800 \mathrm{IU} / \mathrm{d}$ of vitamin $\mathrm{E}$ in the total ration.

\section{MATERIALS AND METHODS}

\section{Animals, Diets, and Feed Samples}

All surgical and animal handling procedures were approved prior to conducting this study by the University of Nebraska Animal Care and Use Committee. Two Angus steers fitted with flexible ruminal and proximal duodenal cannulas and weighing approximately $650 \mathrm{~kg}$ were housed in individual pens and offered 1 of 2 dietary treatments (Table 1): 1) control, containing 0\% WCGF, and 2) WCGF treatment, a diet containing 37.9\% WCGF (DM basis). These diets were similar to those fed to lactating cows in the experiment outlined by Kononoff et al. (2006). Diets were fed twice daily in a crossover design with 4 -wk periods. Amounts equal to $2.1 \%$ of the BW were offered each day, and animals had free access to water. The dRUP for 12 feedstuffs were estimated using in situ and mobile bag techniques (Haugen et al., 2006). The CP contents of individual feeds used for ruminal and intestinal incubation are listed in Table 2 and are similar to estimated values of the NRC (2001).

\section{In Vitro DM Digestibility}

The rate of passage $\left(\mathrm{k}_{\mathrm{p}}\right)$ for the forages was calculated using in vitro DM digestibility (IVDMD) values as described by Haugen et al. (2006). Briefly, DM digestibil-
Table 2. Crude protein (\% of DM) content and standard deviation of selected feed ingredients

\begin{tabular}{lcc}
\hline Feedstuff & CP & SD \\
\hline Alfalfa hay & 23.3 & 0.28 \\
Alfalfa haylage & 27.2 & 0.34 \\
Brome grass hay & 18.6 & 0.20 \\
Corn bran & 17.7 & 0.22 \\
Corn silage & 10.2 & 0.21 \\
Ground corn & 10.1 & 0.32 \\
Soybean meal, 48.5\% & 50.1 & 1.04 \\
Soyhulls & 13.0 & 0.48 \\
Whole cottonseed $_{\text {Wet corn gluten feed }}$ & 27.4 & 2.07 \\
Dried distillers grains $_{\text {Nonenzymatically browned soybean meal }^{1}}$ & 24.9 & 0.03 \\
\hline
\end{tabular}

${ }^{1}$ LignoTech (Rothschild, WI).

ity was determined using the method of Tilley and Terry (1963) and was modified by the addition of $1 \mathrm{~g}$ of urea/L of McDougall's buffer (Weiss, 1994). For this procedure, samples were freeze-dried $\left(-50^{\circ} \mathrm{C}\right)$ for $72 \mathrm{~h}$ and ground through a 1.0-mm screen. Klopfenstein et al. (2001) proposed that the $\mathrm{k}_{\mathrm{p}}$ of forages could be estimated from determining the IVDMD, and $\mathrm{k}_{\mathrm{p}}$ has been used to estimate in situ ruminal incubation for determination of the RUP fraction of brome grass and legume grass hay (Haugen et al., 2006) according to the following equations:

$$
\mathrm{k}_{\mathrm{p}}=0.07 \times \operatorname{IVDMD}(\%)-0.20 \text {. }
$$

Using equation [1] to derive an estimate of $k_{p}$ and assuming a 10-h passage lag, equation [2] (Klopfenstein et al., 2001) was used to estimate total mean retention time (TMRT) of $75 \%$ of the material:

$$
\operatorname{TMRT}=\left[\left(1 / \mathrm{k}_{\mathrm{p}}\right)+10\right] \times 0.75 .
$$

The rationale for these equations stems from the understanding that indigestible NDF is related to the rate of passage, with higher indigestible NDF leading to a decrease in the rate of passage (Ellis et al., 1999). The resulting TMRT were $21.9,22.9$, and $24.5 \mathrm{~h}$ for alfalfa hay, alfalfa haylage, and brome hay, respectively (Table 3). Given the estimated TMRT, ruminal incubation times of 22.0, 23.0, and $24.6 \mathrm{~h}$ were assigned to alfalfa hay, alfalfa haylage, and brome hay, respectively. Because of a lack of published data estimating the rate of passage for corn bran, corn gluten feed, and soyhulls, 2 values of $k_{p}$ were used $(6.0$ and $8.0 \% / h)$ to estimate TMRT. As a result of using equation [2], corn bran, corn gluten feed, and soyhulls were assigned incubation times of 30 and $20 \mathrm{~h}$. Samples of soybean meal (SBM), nonenzymatically browned SBM (LignoTech, Rothschild, WI), dried distillers grains plus solubles (DDGS), and dry ground corn were incubated for $16 \mathrm{~h}$. 
Table 3. In vitro DM digestibility (IVDMD), rate of passage $\left(\mathrm{k}_{\mathrm{p}}\right)$, and total mean retention time (TMRT) of alfalfa hay, alfalfa haylage, and brome hay

\begin{tabular}{lcccr}
\hline & \multicolumn{3}{c}{ Forage type } \\
\cline { 2 - 4 } & $\begin{array}{c}\text { Alfalfa } \\
\text { hay }\end{array}$ & $\begin{array}{c}\text { Alfalfa } \\
\text { haylage }\end{array}$ & $\begin{array}{c}\text { Brome } \\
\text { hay }\end{array}$ & SEM $^{1}$ \\
\hline IVDMD, $\%$ & 77.2 & 72.4 & 65.4 & 0.62 \\
$\mathrm{k}_{\mathrm{p}}, \% / \mathrm{h}$ & 5.21 & 4.87 & 4.38 & 0.04 \\
$\mathrm{TMRT},{ }^{3} \mathrm{~h}$ & 21.9 & 22.9 & 24.6 & 0.17 \\
\hline
\end{tabular}

${ }^{1}$ Highest standard error of treatment means is shown.

${ }^{2}$ Rate of passage $=0.07$ IVDMD $(\%)-0.20$.

${ }^{3} \mathrm{TMRT}=\left[\left(1 / \mathrm{k}_{\mathrm{p}}\right)+10\right] \times 0.75$.

\section{In Situ Ruminal or Intestinal Incubation and Degradability}

Prior to determining ruminal degradability, feed samples were freeze-dried $\left(-50^{\circ} \mathrm{C}\right)$ for $72 \mathrm{~h}$, and ground through a $2.0-\mathrm{mm}$ screen for in situ incubation. Approximately 1 to $2 \mathrm{~g}$ of sample was weighed in quadruplicate and placed in $3.5 \times 5 \mathrm{~cm}$ Dacron bags (Ankom Inc., Fairport, NY) with a pore size of $50 \mu \mathrm{m}$ and then heatsealed (Vanzant et al., 1998). Dacron bags were then placed in mesh bags (50 Dacron bags/mesh bag) also containing a 100-g weight and placed within the ventral sac of the rumen of each steer. Following rumen incubation, half the bags were frozen for later analysis (rumen bags) and the other half (mobile bags) were then incubated in a pepsin and $\mathrm{HCl}$ solution ( $1 \mathrm{~g}$ of pepsin/L and $0.01 \mathrm{~N} \mathrm{HCl}$ ) at $37^{\circ} \mathrm{C}$ for $3 \mathrm{~h}$ to simulate abomasal digestion. After the pepsin- $\mathrm{HCl}$ incubation, 12 mobile bags were inserted into the duodenum of each steer each day, with one bag being inserted every $5 \mathrm{~min}$. The mobile bags were collected in the feces when the first bags appeared ( $12 \mathrm{~h}$ after insertion) up to $24 \mathrm{~h}$ after insertion and were frozen $\left(-4^{\circ} \mathrm{C}\right)$ until all bags were collected. Bags were machine washed using five 1-min washes and 2-min spin cycles. Bags containing alfalfa hay, brome hay, alfalfa haylage, and 20- and 30-h incubations of corn bran, soyhulls, and WCGF were refluxed in a neutral detergent solution to remove microbial contamination (Mass et al., 1999; Haugen et al., 2006). Residues were then analyzed for $\mathrm{N}$ using the combustion method (AOAC, 1996) in a combustion analyzer (Leco FP-528, St. Joseph, MI). Concentration of N was determined directly on residues of SBM, DDGS, cottonseed, and nonenzymatically browned SBM. Digestible RUP (\% of DM) was calculated as the percentage of CP escaping ruminal disappearance but not contained in the residue following intestinal passage.

\section{Chemical Analysis}

All feed and residue samples were analyzed in duplicate for moisture (AOAC, 1996), nitrogen (AOAC, 1996), percentage of ash (AOAC, 1996), and NDF (Van Soest et al., 1991). Neutral detergent insoluble nitrogen and acid detergent insoluble nitrogen were analyzed on $\mathrm{NDF}$ and ADF residues (AOAC, 1996). Heat-stable $\alpha$ amylase (number A3306; Sigma Chemical Co., St. Louis, MO) was included in the NDF procedure (100 $\mu \mathrm{L} / 0.50 \mathrm{~g}$ of sample).

\section{Statistical Analysis}

Data were analyzed as a 2-period crossover design using the PROC MIXED of SAS (Version 9.1, SAS Inst., Inc., Cary, NC). Dietary treatment was treated as a fixed effect, and animal within period was treated as a random effect. Least squares means were separated using the least significant difference method when a significant $(P<0.05) F$-test was detected.

\section{RESULTS AND DISCUSSION}

\section{Chemical Composition of Diets and Feeds}

The ingredient and chemical compositions of experimental diets are listed in Table 1 . The control diet contained 59.6\% forage. The WCGF treatment diet was formulated to contain 37.9\% of WCGF (DM basis) by reducing the proportion of forage by $21.8 \%$ and the amount of concentrate by $17 \%$ (Table 1 ). The CP concentration of the diet containing WCGF was 20.0\% (DM basis) and was higher than that of the control diet (18.2\%). The NDF content was similar: 34.9 and $34.2 \%$ (DM basis) for the WCGF and control diet, respectively.

\section{In Vitro Digestibility, $k_{p}$, and Mean Retention Time}

Klopfenstein et al. (2001) proposed that mean retention times of forages can be estimated from determination of IVDMD. This rationale stems from the understanding that indigestible NDF is related to the rate of passage (Ellis et al., 1999) and has been used to estimate in situ ruminal incubation for determination of the RUP fraction of brome grass and a legume grass hay (Haugen et al., 2006). Table 3 lists the IVDMD, calculated $\mathrm{k}_{\mathrm{p}}$, and $75 \%$ TMRT of alfalfa hay, alfalfa haylage, and brome hay. Estimates of IVDMD for alfalfa hay $(77.2 \%)$ and haylage $(72.4 \%)$ were higher than those of the clipped alfalfa samples observed by Haugen et al. (2006). These differences are likely due to differences in the stage of growth (Van Soest, 1994) but may also have been due to innoculum. Differences in the growth stage of these feedstuffs is evident by the lower CP content of the alfalfa (13.4\%) reported by Haugen et al. (2006) compared with the hay and haylage samples in the current experiment (23.3 and 27.3\%). In contrast to alfalfa samples, the IVDMD of brome hay 
Table 4. Rumen undegradable protein (\% of CP) for selected feed ingredients

\begin{tabular}{lcccr}
\hline & \multicolumn{2}{c}{ Diet $^{1}$} & & \\
\cline { 2 - 3 } Ingredient & Control & WCGF & SEM $^{2}$ & $P$-value \\
\hline Alfalfa hay & 7.94 & 7.86 & 0.35 & 0.86 \\
Alfalfa haylage & 6.00 & 5.93 & 0.12 & 0.66 \\
Brome grass hay & 17.0 & 18.0 & 2.60 & 0.41 \\
Corn bran & & & & \\
20-h incubation & 20.5 & 17.3 & 0.46 & $<0.01$ \\
30-h incubation & 16.6 & 14.9 & 1.08 & 0.05 \\
Corn silage & 19.6 & 18.9 & 0.61 & 0.46 \\
Ground corn & 41.8 & 45.2 & 2.39 & 0.32 \\
Soybean meal, 48.5\% & 26.2 & 30.6 & 7.72 & 0.20 \\
Soyhulls & & & & \\
20-h incubation & 26.2 & 21.8 & 1.48 & $<0.01$ \\
$\quad$ 30-h incubation & 18.5 & 20.5 & 2.75 & 0.06 \\
Whole cottonseed & 12.6 & 12.8 & 0.50 & 0.82 \\
Wet corn gluten feed & & & & \\
20-h incubation & 6.44 & 6.47 & 0.15 & 0.90 \\
30-h incubation & 4.40 & 5.44 & 0.81 & $<0.01$ \\
Dried distillers grains & 46.8 & 39.1 & 4.71 & 0.11 \\
Nonenzymatically browned soybean meal $^{3}$ & 71.6 & 79.7 & 2.08 & $<0.01$ \\
\hline
\end{tabular}

${ }^{1}$ Control = ration containing no amount of wet corn gluten feed; WCGF = ration containing wet corn gluten feed.

${ }^{2}$ Highest standard error of treatment means is shown.

${ }^{3}$ LignoTech (Rothschild, WI).

$(65.4 \%)$ in the current experiment was similar to that reported by Haugen et al. (2006; 64.2\%). Given the IVDMD listed in Table $3, \mathrm{k}_{\mathrm{p}}$ were estimated as 5.21 , 4.87 , and $4.38 \% / \mathrm{h}$ and $75 \%$ TMRT were estimated as $21.9,22.9$, and $24.6 \mathrm{~h}$ for alfalfa hay, alfalfa haylage, and brome hay, respectively. Because time of incubation will affect RUP estimates, some caution should be used when interpreting these data and applying them to mature dairy animals. The current methodology to predict the $\mathrm{k}_{\mathrm{p}}$ is based on the observation of the relationship between digestibility and passage in ruminants (Ellis et al., 1999). For beef animals, this observation was used to develop a method to estimate the $\mathrm{k}_{\mathrm{p}}$ (Klopfenstein et al., 2001) and was used in the current study. Unfortunately, the differences between beef animals and dairy animals have been neither evaluated nor tested, but this should be an area of future research.

\section{Estimates of RUP and Total Tract Digestibility}

Estimates for RUP, as determined by the proportion of CP disappearing from the bag after ruminal incubation, are listed in Table 4 . The rumen was the main site of CP digestion for all feedstuffs except nonenzymatically browned SBM, of which, on average, $75.7 \%$ escaped rumen digestion. The lowest proportion of RUP in forage samples was observed on alfalfa haylage, averaging 5.97\% of CP across the experimental diets (Table 4). As expected, as the time of ruminal incubation increased for soyhulls, corn bran, and WCGF, the RUP estimate decreased and resulted in declining RUP estimates. These were the only feeds for which multiple incubation times were used. When using the mobile bag procedure to determine dRUP, estimates of total tract indigestible protein and RUP are needed [1 - (total tract indigestible protein/RUP)]. It should be noted that when using single time points to estimate RUP, final values are highly dependent on the time of rumen incubation. Estimates of RUP for SBM, DDGS, and nonenzymatically browned SBM are consistent with literature values derived from 16-h ruminal incubation (Erasmus et al., 1994). Similarly, the RUP values for forages are consistent with the values of others who have used similar incubation times and some means of accounting for microbial attachment (Haugen et al., 2006). However, estimates in the current experiment are lower than those reported by researchers using shorter incubation times or no correction for contamination of microbial protein (de Boer et al., 1987; Von Keyserlingk et al., 1996).

Despite some statistical differences, no consistent effect of experimental diet on the estimates of RUP was observed. Diets containing WCGF resulted in slightly lower estimates of RUP in corn bran incubated for 20 and $30 \mathrm{~h}$ (17.3 vs. $20.5 \pm 0.46$ and 14.9 vs. $16.6 \pm 1.08 \%$ $\mathrm{CP})$, and soyhulls incubated for $20 \mathrm{~h}$ (21.8 vs. $26.2 \pm$ $1.48 \% \mathrm{CP})$. In comparison, estimated RUP contained in WCGF (30 h: 5.44 vs. $4.40 \pm 0.81 \% \mathrm{CP}$ ) and nonenzymatically browned SBM (79.74 vs. $71.64 \pm 2.08 \% \mathrm{CP})$ were observed to be higher in animals consuming 
Table 5. Total tract NDF and DM digestibility of selected feed ingredients

\begin{tabular}{|c|c|c|c|c|}
\hline \multirow[b]{2}{*}{ Ingredient } & \multicolumn{2}{|c|}{ Diet $^{1}$} & \multirow[b]{2}{*}{$\mathrm{SEM}^{2}$} & \multirow[b]{2}{*}{$P$-value } \\
\hline & Control & WCGF & & \\
\hline \multicolumn{5}{|l|}{ NDF digestibility, \% } \\
\hline Alfalfa hay & 51.8 & 56.1 & 2.36 & 0.22 \\
\hline Alfalfa haylage & 49.2 & 49.0 & 1.24 & 0.86 \\
\hline Brome grass hay & 54.5 & 50.8 & 3.92 & 0.08 \\
\hline \multicolumn{5}{|l|}{ Corn bran } \\
\hline 20-h incubation & 28.7 & 31.8 & 1.49 & 0.17 \\
\hline 30-h incubation & 46.8 & 51.2 & 2.43 & 0.13 \\
\hline \multicolumn{5}{|l|}{ Soyhulls } \\
\hline 20-h incubation & 39.4 & 44.2 & 4.0 & 0.02 \\
\hline 30-h incubation & 50.9 & 55.8 & 6.95 & 0.31 \\
\hline \multicolumn{5}{|l|}{ Wet corn gluten feed } \\
\hline 20-h incubation & 36.4 & 39.2 & 3.32 & 0.56 \\
\hline 30-h incubation & 56.0 & 50.3 & 10.69 & 0.03 \\
\hline \multicolumn{5}{|l|}{ DM digestibility, \% } \\
\hline Corn silage & 67.9 & 66.4 & 1.51 & 0.37 \\
\hline Ground corn & 83.9 & 86.7 & 1.32 & 0.14 \\
\hline Soybean meal, $48.5 \%$ & 97.5 & 96.8 & 0.89 & 0.19 \\
\hline Whole cottonseed & 53.8 & 52.2 & 1.47 & 0.45 \\
\hline Dried distillers grains & 80.1 & 77.2 & 1.27 & 0.12 \\
\hline Nonenzymatically browned soybean meal ${ }^{3}$ & 96.3 & 97.5 & 0.34 & 0.03 \\
\hline
\end{tabular}

${ }^{1}$ Control = ration containing no amount of wet corn gluten feed; WCGF = ration containing wet corn gluten feed.

${ }^{2}$ Highest standard error of treatment means is shown.

${ }^{3}$ LignoTech (Rothschild, WI).

WCGF. Given that protein degradability can vary substantially between and within feeds, accurate estimation of protein degradability is important for feed evaluation (Hvelplund and Weisbjerg, 2000). Conditions within the bag are generally assumed to be similar to conditions in the surrounding environment, and these may affect the degradability estimates. Although major differences in in situ protein degradation have been observed when animals are fed diets differing in concentrate and hay (Ørskov et al., 1982), little information exists when co-products replace a portion of the concentrates and forages. Results of the current study suggest that when diets are formulated to contain high levels of WCGF but similar levels of NDF and CP, the differences observed in in situ protein degradation may be small.

Total tract NDF digestibility for alfalfa hay, alfalfa haylage, brome grass hay, corn bran, soyhulls, and WCGF, and DM digestibility for the other feedstuffs are listed in Table 5. Using both cows and heifers, Varel and Kreikemeier (1999) reported that total tract NDF digestibility averaged 50.3 and $54.3 \%$ for alfalfa hay and brome hay, respectively. These values are similar to those in the current experiment $(53.9 \pm 2.36$ and 52.6 $\pm 3.92 \%$ for alfalfa hay and brome hay, respectively), indicating that rumen incubation times of forage samples are similar to the rate of passage in vivo. Justification of rumen incubation times for the nonforage fiber sources may be less clear. Feeds possessing a small particle size are believed to pass out of the rumen rap- idly (Beauchemin and Yang, 2005). The passage of small particles may be delayed if they are trapped in the rumen mat layer, which would consequently extend ruminal retention time (Allen and Grant, 2000). Mean total tract NDF digestibility for corn bran, soyhulls, and WCGF increased with rumen incubation time and ranged from $28.7 \%$ for corn bran incubated for $20 \mathrm{~h}$ to $56.0 \%$ for WCGF incubated for $30 \mathrm{~h}$. The latter observation is $21 \%$ lower than that reported by Boddugari et al. (2001) and may indicate that a 30-h incubation time is not indicative of a passage rate that occurs in vivo. If held true, even though the feeds have a low concentration of RUP, this may also indicate that RUP from nonfiber sources may be overestimated in the current experiment. A consequence of this effect may be an underestimate of the total amount of intestinally digested RUP.

The effect of the experimental diet on total tract digestible CP for individual feedstuffs is listed in Table 6 . The lowest total tract digestibility of $\mathrm{CP}$ was observed on soyhulls incubated in the rumen for $20 \mathrm{~h}$, averaging $82.3 \pm 0.97 \%$ across diets. In comparison, the highest estimate was observed on nonenzymatically browned SBM, averaging $97.9 \pm 0.36 \%$ across diets. In the current experiment, only small statistical differences in total tract digestibility of $\mathrm{CP}$ were observed in steers consuming different diets, and all values were relatively high and similar across feedstuffs and diets. However, total tract digestible $\mathrm{CP}$ from ground corn in- 
Table 6. Total tract digestible $\mathrm{CP}(\%$ of $\mathrm{CP})$ of selected feed ingredients

\begin{tabular}{|c|c|c|c|c|}
\hline \multirow[b]{2}{*}{ Ingredient } & \multicolumn{2}{|c|}{$\operatorname{Diet}^{1}$} & \multirow[b]{2}{*}{$\mathrm{SEM}^{2}$} & \multirow[b]{2}{*}{$P$-value } \\
\hline & Control & WCGF & & \\
\hline Alfalfa hay & 94.5 & 95.1 & 0.28 & 0.15 \\
\hline Alfalfa haylage & 95.0 & 94.5 & 0.21 & 0.12 \\
\hline Brome grass hay & 89.9 & 89.1 & 0.70 & 0.15 \\
\hline \multicolumn{5}{|l|}{ Corn bran } \\
\hline 20-h incubation & 82.3 & 82.9 & 0.49 & 0.36 \\
\hline 30-h incubation & 86.2 & 87.1 & 0.51 & 0.22 \\
\hline Corn silage & 84.1 & 82.9 & 0.77 & 0.28 \\
\hline Ground corn & 86.2 & 88.2 & 1.36 & 0.24 \\
\hline Soybean meal, $48.5 \%$ & 99.5 & 99.1 & 0.17 & 0.19 \\
\hline \multicolumn{5}{|l|}{ Soyhulls } \\
\hline 20-h incubation & 81.9 & 82.7 & 0.97 & 0.14 \\
\hline 30-h incubation & 84.5 & 84.2 & 1.16 & 0.85 \\
\hline Whole cottonseed & 89.8 & 89.3 & 0.37 & 0.38 \\
\hline \multicolumn{5}{|l|}{ Wet corn gluten feed } \\
\hline 20-h incubation & 95.2 & 95.2 & 0.22 & 0.90 \\
\hline 30-h incubation & 96.5 & 95.9 & 0.63 & $<0.01$ \\
\hline Dried distillers grains & 94.8 & 93.5 & 0.70 & 0.20 \\
\hline Nonenzymatically browned soybean meal ${ }^{3}$ & 97.5 & 98.3 & 0.36 & 0.12 \\
\hline
\end{tabular}

creased in animals consuming a diet containing WCGF. A similar response was also observed in total tract DM digestibility. The increases in total tract $\mathrm{CP}$ and $\mathrm{DM}$ digestibility in ground corn may have been in response to a lower supply of starch to the small intestine, which is believed to increase pancreatic $\alpha$-amylase secretions (Harmon, 1993). Although not evaluated in the current experiment, when feeding diets containing similar levels of WCGF, Allen and Grant (2000) observed an increase in digesta passage rate that presumably would also influence the intestinal supply of carbohydrates.

\section{Digestibility of RUP}

The mobile nylon bag method is the most commonly used method to determine protein digestibility in the small intestine of ruminants (Van der Poel et al., 2005). Although an array of publications exist on this topic, individual publications commonly include a small number of feedstuffs (mostly concentrate-type feedstuffs), and these estimates are highly dependent on the method used. For example, the rumen incubation time and procedure have been demonstrated to influence dRUP in forage samples (Beckers et al., 1996). Other major factors that influence estimations of dRUP include bag specification (i.e., pore size and dimensions; Varvikko and Vanhatalo, 1990) and site of bag recovery (ileum vs. feces; Hvelplund and Weisbjerg, 2000). Additionally, the type of method used to correct for microbial attachment onto residual particles may influence estimation of $\mathrm{N}$ digestibility. Two of the most common methods are to determine purine derivatives as a microbial protein marker (Zinn and Owens, 1986) and refluxing the residue in a neutral detergent solution (Klopfenstein et al., 2001). When using forage samples, these methods were demonstrated to be highly correlated, but the latter was also demonstrated to be less variable and less laborious (Klopfenstein et al., 2001), and as a result, it was used in the current experiment.

A major objective of this experiment was to evaluate the dRUP fraction of common dairy feedstuffs. Digestibility values of the RUP fraction are reported in Table 7. In the current experiment, the dRUP from brome grass averaged $38.1 \pm 5.34 \% \mathrm{CP}$ across treatments, which is similar to estimates reported by Haugen et al. (2006) but is much lower than tabular NRC (2001) values, which range between 65 and $70 \%$ CP. Similarly, the estimated dRUP for alfalfa hay and haylage averaged 33.0 and $15.5 \% \mathrm{CP}$, which is lower than the estimate of alfalfa hay $(66.7 \% \mathrm{CP})$ reported by de Boer et al. (1987) and tabular NRC (2001) values (70 and 65\% CP). The NRC (2001) publication outlines the dRUP to be $70 \%$ for corn silage and $90 \%$ for ground corn. Again, these values are considerably higher than those observed in the current experiment, where mean dRUP values for corn silage and ground corn were $19.9 \pm 3.76 \%$ and $70.9 \pm 3.74 \%$, respectively. The low dRUP of forages in the current study is consistent with a previous study (Haugen et al., 2006), thus suggesting that tabular dRUP values of the NRC (2001) may be overestimated.

In the current experiment, dRUP of soyhulls and WCGF were also observed to be lower than tabular 
Table 7. Intestinal RUP digestibility (\% of RUP) of selected feed ingredients

\begin{tabular}{|c|c|c|c|c|}
\hline \multirow[b]{2}{*}{ Ingredient } & \multicolumn{2}{|c|}{$\operatorname{Diet}^{1}$} & \multirow[b]{2}{*}{$\mathrm{SEM}^{2}$} & \multirow[b]{2}{*}{$P$-value } \\
\hline & Control & WCGF & & \\
\hline Alfalfa hay & 29.5 & 36.5 & 4.58 & 0.16 \\
\hline Alfalfa haylage & 17.2 & 13.8 & 1.59 & 0.15 \\
\hline Brome grass hay & 39.9 & 38.4 & 5.34 & 0.65 \\
\hline \multicolumn{5}{|l|}{ Corn bran } \\
\hline 20-h incubation & 13.5 & 7.87 & 3.21 & 0.18 \\
\hline 30-h incubation & 20.4 & 14.5 & 2.47 & 0.04 \\
\hline Corn silage & 22.1 & 17.7 & 3.76 & 0.23 \\
\hline Ground corn & 70.1 & 71.7 & 2.79 & 0.53 \\
\hline Soybean meal, $48.5 \%$ & 99.2 & 97.7 & 0.77 & 0.15 \\
\hline \multicolumn{5}{|l|}{ Soyhulls } \\
\hline 20 -h incubation & 31.3 & 20.3 & 1.41 & $<0.01$ \\
\hline 30-h incubation & 15.1 & 27.8 & 7.32 & 0.06 \\
\hline Whole cottonseed & 96.8 & 96.7 & 0.12 & 0.36 \\
\hline \multicolumn{5}{|l|}{ Wet corn gluten feed } \\
\hline 20-h incubation & 25.9 & 25.0 & 3.58 & 0.87 \\
\hline 30-h incubation & 20.3 & 24.1 & 2.60 & 0.32 \\
\hline Dried distillers grains & 88.7 & 83.6 & 1.54 & 0.03 \\
\hline Nonenzymatically browned soybean meal ${ }^{3}$ & 95.8 & 97.3 & 0.53 & 0.07 \\
\hline
\end{tabular}

NRC (2001) estimates (70 and $85 \%$ for soyhulls and corn gluten feed, respectively). Across treatments, the mean dRUP of soyhulls was $25.8 \pm 1.14 \%$ and was 25.4 $\pm 3.58 \%$ for corn gluten feed for the 20 -h incubation. As expected, these values decreased when incubated for $30 \mathrm{~h}(21.4 \pm 7.32 \%$ and $22.2 \pm 2.60 \%$ for soyhulls and corn gluten feed, respectively). One possible reason for the observed discrepancy is the use of a neutral detergent solution to correct for microbial contamination of the residue. Although the use of neutral detergent insoluble nitrogen to measure RUP and total tract digestibility of forage protein have been validated (Haugen et al., 2006), research has not been conducted on nonforage fiber sources. In the case of forage, the neutral detergent solution is assumed to remove microbes attached to the sample particles while not affecting RUP. In the current experiment, and in the cases of WCGF and corn bran, we assumed the same. For nonforage fiber sources such as WCGF, it is possible that a portion of the proteins may have remained in the residue but were soluble in the neutral detergent solution, resulting in lower estimates of dRUP (Klopfenstein et al., 2001). Given the high degradability and small amount of protein in most nonforage fiber sources, violation of our assumption may result in only relatively small errors, especially when using mobile bags. Nonetheless, these results further illustrate the need for an accurate and robust procedure that may be used to correct for microbial $\mathrm{N}$ across a variety of feed types.

Samples of ground corn and protein sources (cottonseed, DDGS, SBM, and nonenzymatically browned
SBM) were not corrected for microbial contamination because it is generally assumed that there is little microbial attachment to concentrate feeds. Generally, dRUP estimates were similar to published results. On average, the dRUP for ground corn was $70.9 \pm 0.53 \%$, which is similar to that reported by Erasmus et al. (1994). The observed estimated dRUP for SBM averaged $98.5 \%$ and is similar to the $92.6 \%$ reported by Beckers et al. (1996) and 99\% reported by Frydrych (1992). In addition, the mean dRUP for DDGS was 86.1 $\pm 1.54 \%$ and is similar to that reported by Masoero et al. (1994). As expected, the dRUP estimate for nonenzymatically browned SBM was high $(96.5 \pm 0.53 \%)$ and was similar to that reported by Weisbjerg et al. (1996). For cottonseed, dRUP was greater than expected. The observed estimated dRUP for whole cottonseed averaged $967 \%$ of the CP and is higher than the value reported by Arieli et al. $(1989 ; 64 \%)$ but is similar to that reported by Erasmus et al. (1994). These results also suggest that total tract digestibility of protein is not dependent on the degree of ruminal degradation (Beckers et al., 1996). For example, compared with nonenzymatically browned SBM, SBM had $37 \%$ as much RUP, but total tract digestibility was similar.

A second major objective of this experiment was to evaluate the effect of diet on dRUP estimates using the mobile bag procedure. Although the effect of diet composition on ruminal in situ measurements has been evaluated (Vanzant et al., 1998), the effects on intestinal digestibility are not well understood. For most feedstuffs, dRUP was not affected by dietary treatment (Ta- 
ble 7). In animals consuming WCGF, dRUP tended to be higher for soyhulls incubated for $30 \mathrm{~h}$ (27.8 vs. 15.1 $\pm 1.41 \% \mathrm{CP})$, and nonenzymatically browned $\operatorname{SBM}(97.3$ vs. $95.8 \pm 0.53 \% \mathrm{CP}$ ). For animals consuming WCGF, dRUP of corn bran was lower when incubated for $30 \mathrm{~h}$ (14.5 vs. $20.4 \pm 2.47 \%)$. In the case of soyhulls and DDGS incubated for $20 \mathrm{~h}$, dRUP was observed to be lower in cows consuming WCGF. Given these observations, it is important to note that the size of the effects for these statistical differences is small. Although secretion of pancreatic trypsin and chymotrypsin has been induced by diet in nonruminants, this area has not been well explored in ruminants. In summary, the rumen is a major site of protein degradation, and factors that influence the ruminal microbial population are also believed to affect in situ estimates of the rate and extent of ruminal digestion (Vanzant et al., 1998). In comparison, dietary factors are likely to have a much smaller effect on the environment of the lower gut, where digestion is mediated by secretions of the liver, pancreas, and small intestinal mucosa (Merchen, 1988).

\section{CONCLUSIONS}

The intestinal digestibility of RUP for common dairy feeds was evaluated using the mobile bag technique. Estimates of the amount of RUP reaching the intestine may be influenced by ruminal incubation time, and future work should be aimed at methods that may be used to determine the rate of passage rapidly and accurately in dairy animals. Nonetheless, this research suggests that tabular values for dRUP in forages published by the NRC (2001) may be overestimated. This experiment also evaluated the effect of diet on intestinal dRUP, which did not appear to result in consistent effects on intestinal digestibility of individual feeds. Practically, this research suggests that further research should be conducted to more accurately describe the intestinal dRUP for common dairy feeds, but if the mobile bag technique is used, the diet offered to the animal may have only small effects.

\section{REFERENCES}

Allen, D. M., and R. J. Grant. 2000. Interactions between forage and wet corn gluten feed as sources of fiber in diets for lactating dairy cows. J. Dairy Sci. 83:322-331.

AOAC. 1996. Official Methods of Analysis. 16th ed. AOAC Int., Arlington, VA.

Arieli, A., I. Bruckental, and E. Smoler. 1989. Prediction of duodenal nitrogen supply from degradation or organic and nitrogenous matter in situ. J. Dairy Sci. 72:2532-2539.

Beauchemin, K. A., and W. Z. Yang. 2005. Effects of physically effective fiber on intake, chewing activity, and ruminal acidosis for dairy cows fed diets based on corn silage. J. Dairy Sci. 88:2117-2129.
Beckers, Y., A. Thewis, and B. Maudoux. 1996. Intestinal digestibility of rumen undegraded $\mathrm{N}$ of concentrates measured by the mobile nylon bag technique. Anim. Feed Sci. Technol. 61:305-323.

Boddugari, K., R. J. Grant, R. Stock, and M. Lewis. 2001. Maximal replacement of forage and concentrate with a new wet corn milling product for lactating dairy cows. J. Dairy Sci. 84:873-884.

de Boer, G., J. J. Murphy, and J. J. Kennedy. 1987. Mobile nylon bag for estimating intestinal availability of rumen undegradable protein. J. Dairy Sci. 70:977-982.

Ellis, W. C., D. P. Poppi, J. H. Matis, H. Lippke, T. M. Hill, and F. M. Rouquette. 1999. Dietary-digestive-metabolic interactions determining the nutritive potential of ruminant diets. Pages 432 481 in Nutritional Ecology of Herbivores. H. G. Jung and G. C. Fahey, Jr., ed. Am. Soc. Anim. Sci., Savoy, IL.

Erasmus, L. J., P. M. Botha, and C. W. Cruywagen. 1994. Amino acid profile and intestinal digestibility of dairy cows of rumenundegradable protein from various feedstuffs. J. Dairy Sci. $77: 541-551$.

Frydrych, Z. 1992. Intestinal digestibility of rumen undegraded protein of various feeds as estimated by the mobile bag technique. Anim. Feed Sci. Technol. 37:161-172.

Harmon, D. L. 1993. Nutritional regulation of postruminal digestive enzymes in ruminants. J. Dairy Sci. 76:2102-2111.

Haugen, H. L., S. K. Ivan, J. C. MacDonald, and T. J. Klopfenstein. 2006. Determination of undegradable intake protein digestibility of forages using the mobile nylon bag technique. J. Anim. Sci. 84:886-893.

Hvelplund, T., and M. R. Weisbjerg. 2000. In situ techniques for the estimation of protein degradability and postrumen availability. Pages 233-258 in Forage Evaluation in Ruminant Nutrition. D. I. Given, E. Owen, R. F. E. Axford, and H. M. Omed, ed. CABI Publishing, New York, NY

Klopfenstein, T. J., R. A. Mass, K. W. Creighton, and H. H. Patterson. 2001. Estimating forage protein degradation in the rumen. J. Anim. Sci. 79(E Suppl.):E208-E217.

Kononoff, P. J., S. Ivan, W. Matzke, R. J. Grant, R. Stock, and T. J. Klopfenstein. 2006. Milk production of dairy cows fed a wet corn gluten feed during the dry period and lactation. J. Dairy Sci. 89:2608-2617.

Macken, C. N., G. E. Erickson, T. J. Klopfenstein, and R. A. Stock. 2004. Effects of concentration and composition of wet corn gluten feed in steam-flaked corn-based finishing diets. J. Anim. Sci. 82:2718-2723.

Masoero, F., L. Fiorentini, F. Rossi, and A. Piva. 1994. Determination of nitrogen intestinal digestibility in ruminants. Anim. Feed Sci. Technol. 48:253-263.

Mass, R. A., G. P. Lardy, R. J. Grant, and T. J. Klopfenstein. 1999 In situ neutral detergent insoluble nitrogen as a method for measuring forage protein degradability. J. Anim. Sci. 77:1565-1571.

Merchen, N. R. 1988. Digestion, absorption and excretion in ruminants. Pages 172-201 in The Ruminant Animal, Digestive Physiology and Nutrition. D. C. Church, ed. Waveland Press, Prospect Heights, IL.

NRC. 2001. Nutrient Requirements of Dairy Cattle. National Academy Press, Washington, DC.

Ørskov, E. R. 1982. Protein Nutrition in Ruminants. Academic Press, New York, NY.

Schwab, C. G., T. P. Tylutki, R. S. Ordway, C. Sheaffer, and M. D. Stern. 2003. Characterization of proteins in feeds. J. Dairy Sci. 86(E Suppl.):E88-E103.

Tilley, J. M. A., and R. A. Terry. 1963. A two-stage technique for the in vitro digestion of forage crops. J. Brit. Grassl. Soc. 18:104-111.

Van der Poel, A. F. B., E. Prestlokken, and J. O. Goelema. 2005. Feed processing: Effects on nutrient degradation and digestibility. Pages 627-661 in Quantitative Aspects of Ruminant Digestion and Metabolism. 2nd ed. J. Dijkstra, J. M. Forbes, and J. France, ed. CABI Publishing, New York, NY.

Van Soest, P. J. 1994. Nutritional Ecology of the Ruminant. 2nd ed. Pages 292-296. Cornell University Press, Ithaca, NY.

Van Soest, P. J., J. B. Robertson, and B. A. Lewis. 1991. Symposium: Carbohydrate methodology, metabolism, and nutritional implica- 
tions in dairy cattle. Methods for dietary fiber, neutral detergent fiber and non-starch polysaccharides in relation to animal nutrition. J. Dairy Sci. 74:3583-3597.

Vanzant, E. S., R. C. Cochran, and E. C. Titgemeyer. 1998. Standardization of in situ techniques for ruminant feedstuff evaluation. J. Anim. Sci. 76:2717-2729.

Varel, V. H., and K. K. Kreikemeier. 1999. Low- and high-quality forage utilization by heifers and mature beef cows. J. Anim. Sci. $77: 2774-2780$.

Varvikko, T., and A. Vanhatalo. 1990. The effect of differing types of cloth and of contamination by non-feed nitrogen on intestinal digestion estimates using porous synthetic-fibre bags in a cow. Br. J. Nutr. 63:221-229.
Von Keyserlingk, M. A. G., M. L. Swift, R. Puchala, and J. A. Shelford. 1996. Degradability characteristics of dry matter and crude protein of forages in ruminants. Anim. Feed Sci. Technol. 57:291-311.

Weisbjerg, M. R., T. Hvelplund, S. Hellberg, S. Ilsson, and S. Sanne. 1996. Effective rumen degradability and intestinal digestibility of individual amino acids in different concentrates determined in situ. Anim. Feed Sci. Technol. 62:179-188.

Weiss, W. P. 1994. Estimation of digestibility of forages by laboratory methods. Pages 644-681 in Forage Quality, Evaluation, and Utilization. G. C. Fahey, Jr., ed. Am. Soc. Agron. Inc., Crop Sci. Soc. Am., and Soil Sci. Soc. Am., Inc., Madison, WI.

Zinn, R. A., and F. N. Owens. 1986. A rapid procedure for purine measurement and its use for estimating net ruminal protein synthesis. Can. J. Anim. Sci. 66:157-166. 